\title{
Dose Effect and Mode of Inheritance of Diabetogenic Gene on Mouse Chromosome 11
}

\author{
Naru Babaya, ${ }^{1}$ Hironori Ueda, ${ }^{2}$ Shinsuke Noso, ${ }^{1}$ Yoshihisa Hiromine, ${ }^{1}$ Koji Nojima, ${ }^{3}$ \\ Michiko Itoi-Babaya, ${ }^{3}$ Misato Kobayashi, ${ }^{4}$ Tomomi Fujisawa, ${ }^{3}$ and Hiroshi Ikegami ${ }^{1}$ \\ ${ }^{1}$ Department of Endocrinology, Metabolism and Diabetes, Kinki University Faculty of Medicine, 377-2 Ohno-higashi, \\ Osaka-sayama, Osaka 589-8511, Japan \\ ${ }^{2}$ Department of Molecular Endocrinology, Osaka University Graduate School of Medicine, Suita, Osaka 565-0871, Japan \\ ${ }^{3}$ Department of Geriatric Medicine, Osaka University Graduate School of Medicine, Suita, Osaka 565-0871, Japan \\ ${ }^{4}$ Department of Applied Molecular Bioscience, Graduate School of Bioagricultural Sciences, Nagoya University, Nagoya, \\ Aichi 464-8601, Japan
}

Correspondence should be addressed to Hiroshi Ikegami; ikegami@med.kindai.ac.jp

Received 23 November 2012; Accepted 25 December 2012

Academic Editor: Norihide Yokoi

Copyright (C) 2013 Naru Babaya et al. This is an open access article distributed under the Creative Commons Attribution License, which permits unrestricted use, distribution, and reproduction in any medium, provided the original work is properly cited.

\begin{abstract}
The quantitative trait locus (QTL) mapping in segregating crosses of NSY (Nagoya-Shibata-Yasuda) mice, an animal model of type 2 diabetes, with nondiabetic strain $\mathrm{C} 3 \mathrm{H} / \mathrm{He}$ mice has identified diabetogenic QTLs on multiple chromosomes. The QTL on chromosome 11 (Chr11) (Nidd1n) showing the largest effect on hyperglycemia was confirmed by our previous studies with homozygous consomic mice, $\mathrm{C} 3 \mathrm{H}-11^{\mathrm{NSY}}$, in which the NSY-derived whole Chr11 was introgressed onto control C3H background genes. $\mathrm{C} 3 \mathrm{H}-11^{\mathrm{NSY}}$ mice also showed a streptozotocin (STZ) sensitivity. In the present study, we constructed heterozygous $\mathrm{C} 3 \mathrm{H}-11^{\mathrm{NSY}}$ mice and the phenotypes were analyzed in detail in comparison with those of homozygous $\mathrm{C} 3 \mathrm{H}-11^{\mathrm{NSY}}$ and $\mathrm{C} 3 \mathrm{H}$ mice. Heterozygous $\mathrm{C} 3 \mathrm{H}-11^{\mathrm{NSY}}$ mice had significantly higher blood glucose levels and STZ sensitivity than those in $\mathrm{C} 3 \mathrm{H}$ mice. Hyperglycemia and STZ sensitivity in heterozygous C $3 \mathrm{H}-11^{\mathrm{NSY}}$ mice, however, were not as severe as in homozygous C $3 \mathrm{H}-11^{\text {NSY }}$ mice. The body weight and fat pad weight in heterozygous $\mathrm{C} 3 \mathrm{H}-11^{\mathrm{NSY}}$ mice were similar to those in $\mathrm{C} 3 \mathrm{H}$ and homozygous $\mathrm{C} 3 \mathrm{H}-11^{\text {NSY }}$ mice. These data indicated that the introgression of Chr11 of the diabetes-susceptible NSY strain onto diabetes-resistant $\mathrm{C} 3 \mathrm{H}$ caused marked changes in the glucose tolerance and STZ susceptibility even in a heterozygous state, and suggested that the mode of inheritance of a gene or genes on Chr11 for hyperglycemia and STZ sensitivity is additive.
\end{abstract}

\section{Introduction}

Patients with type 2 diabetes have a complex phenotype with impaired insulin secretion, insulin resistance both in the liver and peripheral tissues, and increased hepatic glucose production, all of which contribute to the development of overt hyperglycemia [1]. Genetic dissection of type 2 diabetes in humans is difficult because of the genetic heterogeneity, multigenicity, and environmental variation. One way to overcome this complexity in the human population is to use well-defined animal models of type 2 diabetes.

The NSY (Nagoya-Shibata-Yasuda) mouse is an inbred animal model with a spontaneous development of type 2 diabetes $[2,3]$. The animal is moderately obese, and both impaired insulin response to glucose and insulin resistance contribute to diabetes $[2,3]$. Quantitative trait locus (QTL) mapping in segregating crosses of NSY with the nondiabetic strain $\mathrm{C} 3 \mathrm{H} / \mathrm{He}$ has identified diabetes-related QTLs on multiple chromosomes $[4,5]$. Using the consomic strategy, we previously dissected a quantitative trait locus (QTL), Nidd1n, on chromosome 11 (Chr11) affecting glucose-related phenotypes $[6,7]$. The constructed strain, $\mathrm{C} 3 \mathrm{H}-11^{\mathrm{NSY}}$, which carries the homozygous NSY-derived diabetes-susceptible Chr11 on $\mathrm{C} 3 \mathrm{H}$-derived diabetes-resistant background genes, showed hyperglycemia [6] and streptozotocin (STZ) sensitivity [7] compared with control $\mathrm{C} 3 \mathrm{H}$ strain. Although these data 
clearly demonstrated the presence of the diabetogenic gene(s) on mouse Chr11, the dose effect and the mode of inheritance of the gene(s) responsible for each diabetes-related phenotype are still unclear. In the present study, we constructed heterozygous $\mathrm{C} 3 \mathrm{H}-11^{\mathrm{NSY}}$ mice, and the phenotypes were analyzed in detail in comparison with those of homozygous $\mathrm{C} 3 \mathrm{H}-11^{\mathrm{NSY}}$ and $\mathrm{C} 3 \mathrm{H}$ mice.

\section{Materials and Methods}

2.1. Animals. NSY mice [2] were originally obtained from the Branch Hospital of the Nagoya University School of Medicine. $\mathrm{C} 3 \mathrm{H} / \mathrm{He}$ mice were purchased from Charles River Laboratories (Kanagawa, Japan). These strains were maintained by a brother-sister mating. Maintained male $\mathrm{C} 3 \mathrm{H} / \mathrm{He}$ mice were used in this study ( $n=8$ for Study $1, n=20$ for Study 2).

The consomic strain, $\mathrm{C} 3 \mathrm{H}-11^{\mathrm{NSY}}$, was previously constructed using a marker-assisted method [6, 7]. Shortly, F1 male mice were obtained by mating $(\mathrm{NSY} \times \mathrm{C} 3 \mathrm{H} / \mathrm{He})$. These males were then mated with $\mathrm{C} 3 \mathrm{H} / \mathrm{He}$ females, and their male progeny, heterozygous for Chr11, were used for the next generation. This process was repeated until all the markers for background typing became homozygous for the $\mathrm{C} 3 \mathrm{H}$ genotype (N6 or N7), at which point a heterozygous consomic strain was obtained and the male mice were used in this study (heterozygous $\mathrm{C} 3 \mathrm{H}-11^{\mathrm{NSY}}: n=8$ for Study 1 ).

Mice heterozygous for Chr11 were intercrossed to obtain mice homozygous for Chr11. Constructed homozygous $\mathrm{C} 3 \mathrm{H}-11^{\text {NSY }}$ mice were maintained by brother-sister mating. To analyze male heterozygous $\mathrm{C} 3 \mathrm{H}-11^{\mathrm{NSY}}$ mice in this study ( $n=20$ for Study 2), male homozygous $\mathrm{C} 3 \mathrm{H}-11^{\mathrm{NSY}}$ were mated with female $\mathrm{C} 3 \mathrm{H} / \mathrm{He}$ mice.

All mice had free access to tap water and a standard diet (CRF-1: Oriental Yeast, Tokyo, Japan) in an air-conditioned room $\left(22-25^{\circ} \mathrm{C}\right)$ with a $12 \mathrm{~h}$ light-dark cycle $(6: 00-18: 00 \mathrm{~h})$ in the animal facilities of the Osaka University Graduate School of Medicine. The experiment was approved by the Osaka University Graduate School of Medicine Ethics Committee.

2.2. Analysis of Hyperglycemia-Related Phenotypes in Heterozygous $\mathrm{C} 3 \mathrm{H}-11^{\text {NSY }}$ and $\mathrm{C} 3 \mathrm{H}$ (Study 1). Glucose tolerance was assessed by intraperitoneal glucose tolerance test (ipGTT) ( $2 \mathrm{~g}$ glucose/kg body weight) in overnight-fasted mice at 48 weeks of age, and blood glucose levels were measured at 0, 30, 60, 90, and 120 min using Glutest E (Kyoto Daiichi Kagaku, Kyoto, Japan). The area under the glucose curve (gAUC) was calculated according to the trapezoid rule from the glucose measurements at $0,30,60,90$, and $120 \mathrm{~min}$.

Insulin secretion in response to glucose was assessed by intraperitoneal glucose tolerance test (ipGTT) (2 g glucose/kg body weight) in overnight-fasted mice at 52 weeks of age, and blood glucose levels and plasma insulin levels were measured at 0,15 , and $30 \mathrm{~min}$. Plasma insulin level was measured using an enzyme-immunosorbent assay (ELISA) kit (Morinaga, Yokohama, Japan). Insulin values in micrograms per liter obtained by ELISA were converted to picomoles per liter by multiplying by a factor of 174 . Incremental glucose $(\Sigma \Delta$ glucose) and incremental insulin ( $\Sigma \Delta$ insulin) were calculated from the measurements at 0,15 , and $30 \mathrm{~min}$. Insulinogenic index was calculated as $\Sigma \Delta$ insulin divided by $\Sigma \Delta$ glucose. Insulin resistance was assessed by HOMA-IR, which was calculated from the basal insulin and glucose concentrations.

Anatomical analysis was performed at 54 weeks of age. After body weight measurement, mice were killed under sevoflurane. The liver, epididymal fat pads, and mesenteric fat pads were dissected and weighed.

Hyperglycemia-related phenotypes were compared between heterozygous $\mathrm{C} 3 \mathrm{H}-11^{\mathrm{NSY}}$ and $\mathrm{C} 3 \mathrm{H}$ and between heterozygous $\mathrm{C} 3 \mathrm{H}-11^{\mathrm{NSY}}$ and homozygous $\mathrm{C} 3 \mathrm{H}-11^{\mathrm{NSY}}$, which have been reported previously [6].

\subsection{Analysis of Streptozotocin Sensitivity in Heterozygous} $\mathrm{C} 3 \mathrm{H}-11^{\mathrm{NSY}}$ (Study 2). The mice received a single injection of STZ at a dose of $175 \mathrm{mg} / \mathrm{kg}$ body weight at 12 weeks of age. STZ was dissolved in sodium citrate buffer (Wako Pure Chemical Industries, Ltd., Osaka, JAPAN) and immediately injected intraperitoneally. Blood glucose level and body weight were measured on days $0,1,2,4,5,7$, and 8 after injection. Mice with a blood glucose level higher than $11.1 \mathrm{mmol} / \mathrm{L}$ were considered hyperglycemic. Homozygous $\mathrm{C} 3 \mathrm{H}-11^{\mathrm{NSY}}$ and $\mathrm{C} 3 \mathrm{H}$ data have been reported previously [7] and reanalyzed in this study. Although data of a small number of heterozygous $\mathrm{C} 3 \mathrm{H}-11^{\mathrm{NSY}}$ have been described [7], we constructed a large number of heterozygous $\mathrm{C} 3 \mathrm{H}-11^{\mathrm{NSY}}$ $(n=20)$.

2.4. Statistical Analysis. All values are expressed as mean \pm SEM. Statistical analysis was performed by Mann-Whitney $U$ test. Survival curves were analyzed with the log-rank test. Statistical tests were performed using PRISM software (Graphpad Prism). $P<0.05$ was considered to indicate a statistical significance.

\section{Results}

3.1. Phenotypes of Heterozygous C3H-1 $1^{\text {NSY }}$ Mice (Study 1). Heterozygous $\mathrm{C} 3 \mathrm{H}-11^{\mathrm{NSY}}$ mice showed significantly higher blood glucose levels after fasting $(P<0.05)$ and at all time points after a glucose challenge $(P<0.05)$ than those in $\mathrm{C} 3 \mathrm{H}$ mice (Figure 1), indicating that the introduction of a single dose of NSY-Chr11 converted normoglycemic $\mathrm{C} 3 \mathrm{H}$ mice to hyperglycemic mice. Compared to homozygous $\mathrm{C} 3 \mathrm{H}-11^{\mathrm{NSY}}$ mice [6], however, heterozygous $\mathrm{C} 3 \mathrm{H}-11^{\mathrm{NSY}}$ mice had lower blood glucose levels after fasting $(P<0.01)$ and at all time points after a glucose challenge $(P<0.01)$ (Figure 1$)$, suggesting that NSY-Chr11 influences glucose tolerance in an additive manner.

As shown in Table 1, insulin secretion in response to glucose as assessed by insulinogenic index tended to be lower 


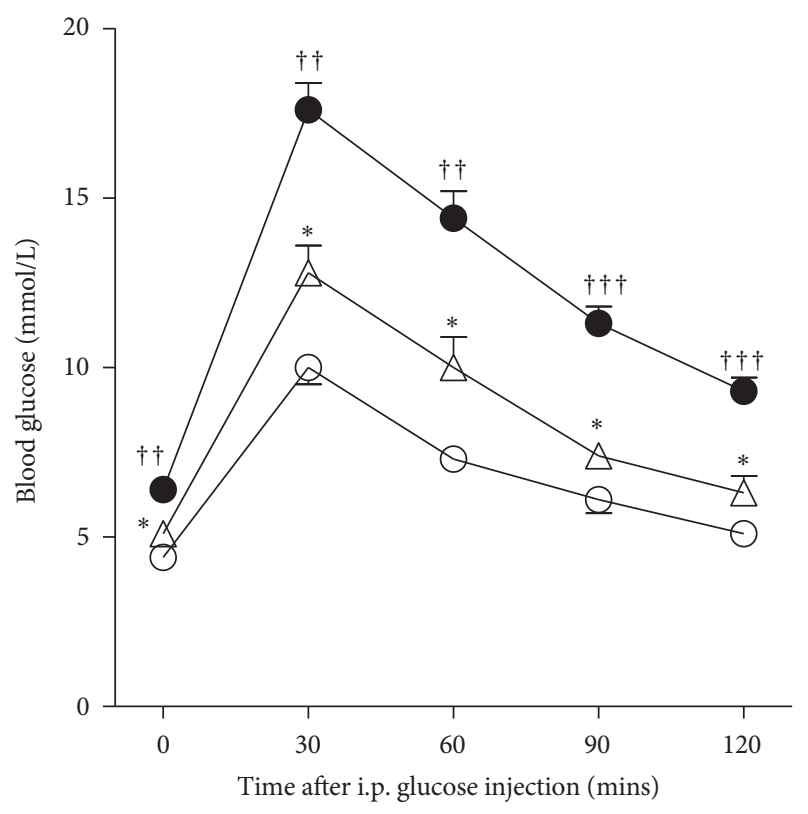

FIGURE 1: Intraperitoneal glucose tolerance test at 48 weeks of age in heterozygous $\mathrm{C} 3 \mathrm{H}-11^{\mathrm{NSY}}$ ( $n=8$, white triangles), C3H mice $(n=8$; white circles), and homozygous $\mathrm{C} 3 \mathrm{H}-11^{\mathrm{NSY}}(n=28$, black circles, [6]). Values are mean \pm SEM. ${ }^{*} P<0.05$ compared with $\mathrm{C} 3 \mathrm{H}$ mice (Mann-Whitney $U$ test). ${ }^{\dagger \dagger} P<0.01$ and ${ }^{\dagger \dagger \dagger} P<0.001$ compared with heterozygous $\mathrm{C} 3 \mathrm{H}-11^{\mathrm{NSY}}$ (Mann-Whitney $U$ test).

in heterozygous $\mathrm{C} 3 \mathrm{H}-11^{\mathrm{NSY}}$ than in $\mathrm{C} 3 \mathrm{H}$ mice and was similar to that in homozygous $\mathrm{C} 3 \mathrm{H}-11^{\mathrm{NSY}}$ mice. Fasting insulin level ( 0 min in Table 1) and HOMA-IR in heterozygous $\mathrm{C} 3 \mathrm{H}-11^{\mathrm{NSY}}$ tended to be higher than those in $\mathrm{C} 3 \mathrm{H}$ mice.

In the anatomical analysis, body weight in heterozygous $\mathrm{C} 3 \mathrm{H}-11^{\mathrm{NSY}}$ mice was not significantly different from that in $\mathrm{C} 3 \mathrm{H}$ mice (Table 2). Fat pad weight and percent fat pad weight/body weight were not significantly different either. Compared to that in homozygous $\mathrm{C} 3 \mathrm{H}-11^{\mathrm{NSY}}$ mice in our previous study [6], body weight was not significantly different. Fat pad weight and percent fat pad weight/body weight were not significantly different either. Those in heterozygous $\mathrm{C} 3 \mathrm{H}-11^{\mathrm{NSY}}$ mice, however, tended to be lower than those in homozygous $\mathrm{C} 3 \mathrm{H}-11^{\mathrm{NSY}}$ mice and similar to those in $\mathrm{C} 3 \mathrm{H}$ mice.

\subsection{Streptozotocin Sensitivity in Heterozygous $\mathrm{C} 3 \mathrm{H}-11^{\mathrm{NSY}}$} (Study 2). Heterozygous $\mathrm{C} 3 \mathrm{H}-11^{\mathrm{NSY}}$ mice showed a higher blood glucose level after streptozotocin injection than $\mathrm{C} 3 \mathrm{H}$ mice (Figure 2(a)), and life table analysis demonstrated a significant difference in survival curves between C $3 \mathrm{H}-11^{\mathrm{NSY}}$ and $\mathrm{C} 3 \mathrm{H}$ mice $(P<0.001)$ (Figure $2(\mathrm{~b}))$, indicating that the introgression of a single dose of Chr11 from STZ sensitive NSY mice converted STZ resistant C3H mice to STZ sensitive. Compared with homozygous $\mathrm{C} 3 \mathrm{H}-11^{\mathrm{NSY}}$ mice, however, heterozygous $\mathrm{C} 3 \mathrm{H}-11^{\mathrm{NSY}}$ mice showed significantly lower blood glucose levels (Figure 2(a)), and life table analysis demonstrated a significant difference in survival curves between homozygous and heterozygous C3H-11 ${ }^{\text {NSY }}$ mice $(P<0.001)$ (Figure $2(b))$, suggesting that NSY-Chr11 influences STZ sensitivity in an additive manner.

\section{Discussion}

This study clearly demonstrated that the introgression of Chr11 of the diabetes-susceptible NSY strain onto the diabetes-resistant $\mathrm{C} 3 \mathrm{H}$ strain caused marked changes in glucose tolerance and STZ susceptibility, even in a heterozygous state. Blood glucose levels of heterozygous $\mathrm{C} 3 \mathrm{H}-11^{\mathrm{NSY}}$ mice were intermediate between those of homozygous $\mathrm{C} 3 \mathrm{H}-11^{\mathrm{NSY}}$ and $\mathrm{C} 3 \mathrm{H}$ mice, suggesting that the mode of inheritance of glucose intolerance is additive.

Our previous studies with reciprocal F1 crosses of NSY and $\mathrm{C} 3 \mathrm{H}$ mice showed a different mode of inheritance depending on the phenotypes studied [8]. Hyperglycemia and fasting plasma insulin showed autosomal dominant inheritance, while impaired insulin secretion and epididymal fat accumulation showed an autosomal recessive mode of inheritance [8]. Since F1 mice are heterozygous for all autosomes, the mode of inheritance observed in our previous study with F1 mice is the combined effect of all chromosomes responsible for each phenotype. In contrast, heterozygous $\mathrm{C} 3 \mathrm{H}-11^{\mathrm{NSY}}$ mice in the present study were heterozygous for only Chr11, while all other chromosomes were homozygous for control $\mathrm{C} 3 \mathrm{H}$ mice, making it possible to clarify the dose effect and mode of inheritance of Chr11 independent of other chromosomes. The data in the present study indicated an additive mode of inheritance for hyperglycemia, which is different from the dominant inheritance of hyperglycemia observed in F1 mice [8]. The differences in mode of inheritance observed in this study with heterozygous $\mathrm{C} 3 \mathrm{H}-11^{\text {NSY }}$ mice and in our previous study with $\mathrm{F} 1$ mice suggest a genetic interaction of Chr11 with other chromosomes. To clarify this, studies with double and triple consomic strains, in which different combinations of chromosomes from NSY mice were introgressed onto $\mathrm{C} 3 \mathrm{H}$ background genes, are now underway.

Our previous studies with homozygous $\mathrm{C} 3 \mathrm{H}-11^{\mathrm{NSY}}$ mice demonstrated that introgression of two doses of Chr11 from NSY mice onto control C3H mice converted STZ resistant C3H mice to STZ sensitive [7]. STZ sensitivity in heterozygous $\mathrm{C} 3 \mathrm{H}-11^{\mathrm{NSY}}$ mice in the present study was intermediate between that of homozygous $\mathrm{C} 3 \mathrm{H}-11^{\mathrm{NSY}}$ and that of $\mathrm{C} 3 \mathrm{H}$ mice, suggesting a dose effect of Chr11 on STZ sensitivity and an additive mode of inheritance for this phenotype.

Although the present study with $\mathrm{C} 3 \mathrm{H}-11^{\mathrm{NSY}}$ mice made it possible to clarify the effect of Chr11 independent of other chromosomes, the additive mode of inheritance of glucose intolerance and STZ sensitivity observed in the present study does not necessarily reflect the effect of a single gene, but rather could result from the combined effect of multiple genes on Chr11. Further studies with congenic and subcongenic strains are necessary to clarify whether or not each phenotype observed in heterozygous $\mathrm{C} 3 \mathrm{H}-11^{\mathrm{NSY}}$ mice is based on a single gene or the combined effect of multiple genes. 
TABLE 1: Insulin secretion and insulin resistance at 52 weeks of age.

\begin{tabular}{|c|c|c|c|c|}
\hline & & $\mathrm{C} 3 \mathrm{H}(n=8)$ & $\begin{array}{c}\mathrm{C} 3 \mathrm{H}-11^{\mathrm{NSY}} \\
\text { (heterozygotes) } \\
(n=8)\end{array}$ & $\begin{array}{c}\mathrm{C} 3 \mathrm{H}-11^{\mathrm{NSY}} \\
\text { (homozygotes) }^{\dagger} \\
(n=26)\end{array}$ \\
\hline \multicolumn{5}{|l|}{ Blood glucose } \\
\hline $0 \mathrm{~min}$ & $(\mathrm{mmol} / \mathrm{L})$ & $5.6 \pm 0.3$ & $5.8 \pm 0.4$ & $6.3 \pm 0.3$ \\
\hline $15 \mathrm{~min}$ & $(\mathrm{mmol} / \mathrm{L})$ & $17.3 \pm 0.6$ & $20.7 \pm 2.9$ & $18.1 \pm 0.5$ \\
\hline $30 \mathrm{~min}$ & $(\mathrm{mmol} / \mathrm{L})$ & $19.7 \pm 1.9$ & $23.4 \pm 2.8$ & $22.8 \pm 0.5$ \\
\hline$\Sigma \Delta \mathrm{gAUC}$ & $(\mathrm{pmol} / \mathrm{L} \times \min )$ & $281.7 \pm 19.6$ & $356.1 \pm 57.7$ & $300.2 \pm 9.3$ \\
\hline \multicolumn{5}{|l|}{ Insulin } \\
\hline $0 \mathrm{~min}$ & $(\mathrm{pmol} / \mathrm{L})$ & $19.6 \pm 5.3$ & $31.7 \pm 7.6$ & $25.7 \pm 2.7$ \\
\hline $15 \mathrm{~min}$ & $(\mathrm{pmol} / \mathrm{L})$ & $140.1 \pm 16.9$ & $112.7 \pm 12.9$ & $106.1 \pm 8.4$ \\
\hline $30 \mathrm{~min}$ & $(\mathrm{pmol} / \mathrm{L})$ & $78.7 \pm 8.1$ & $88.1 \pm 10.7$ & $84.8 \pm 5.7$ \\
\hline$\Sigma \Delta \mathrm{iAUC}$ & $(\mathrm{pmol} / \mathrm{L} \times \min )$ & $2249.8 \pm 252.6$ & $1639.8 \pm 324.4$ & $1649.0 \pm 140.3$ \\
\hline Insulin secretion $^{\dagger \dagger}$ & & $8.6 \pm 1.5$ & $5.8 \pm 1.5$ & $5.6 \pm 0.5$ \\
\hline Insulin sensitivity $^{\dagger \dagger \dagger}$ & & $118.7 \pm 39.9$ & $201.2 \pm 56.9$ & $168.4 \pm 20.9$ \\
\hline
\end{tabular}

TABLE 2: Anatomical analysis at 54 weeks of age.

\begin{tabular}{|c|c|c|c|c|}
\hline & & $\mathrm{C} 3 \mathrm{H}(n=8)$ & $\begin{array}{c}\mathrm{C} 3 \mathrm{H}-11^{\mathrm{NSY}} \\
\text { (Heterozygous) } \\
(n=8)\end{array}$ & $\begin{array}{c}\mathrm{C} 3 \mathrm{H}-11^{\mathrm{NSY}} \\
{\text { (Homozygous })^{\dagger}}_{(n=26)}\end{array}$ \\
\hline Blood glucose (ad lib) & $(\mathrm{mmol} / \mathrm{L})$ & $6.7 \pm 0.4$ & $7.4 \pm 0.5$ & $8.1 \pm 0.2$ \\
\hline Insulin (ad lib) & $(\mathrm{pmol} / \mathrm{L})$ & $135.9 \pm 12.3$ & $172.4 \pm 16.5$ & $226.0 \pm 12.8$ \\
\hline Body weight & (g) & $31.4 \pm 0.8$ & $29.6 \pm 0.8$ & $31.0 \pm 0.5$ \\
\hline Liver & (g) & $1.549 \pm 0.100$ & $1.529 \pm 0.045$ & $1.409 \pm 0.039$ \\
\hline Total fat & (g) & $1.065 \pm 0.109$ & $1.024 \pm 0.070$ & $1.209 \pm 0.072$ \\
\hline Epididymal fat & (g) & $0.522 \pm 0.068$ & $0.527 \pm 0.042$ & $0.707 \pm 0.054$ \\
\hline Mesenteric fat & (g) & $0.543 \pm 0.065$ & $0.497 \pm 0.035$ & $0.502 \pm 0.021$ \\
\hline Total fat/body weight & $(\%)$ & $3.37 \pm 0.29$ & $3.44 \pm 0.18$ & $3.87 \pm 0.19$ \\
\hline
\end{tabular}

Values are total number or mean \pm SEM. Heterozygous C $3 \mathrm{H}-11^{\mathrm{NSY}}$ were compared with C3H and homozygous C3H-11 ${ }^{\mathrm{NSY}}$ by Mann-Whitney $U$ test, but no significant difference was observed. ${ }^{\dagger}$ Data of homozygous $\mathrm{C} 3 \mathrm{H}-11^{\mathrm{NSY}}$ mice were already reported [6].

Our previous studies with homozygous $\mathrm{C} 3 \mathrm{H}-11^{\mathrm{NSY}}$ mice demonstrated that impaired insulin secretion in NSY mice was accounted for mostly by Chr11 and that insulin resistance, which is independent of adiposity and obesity, was accounted for partly by Chr11 [6]. In the present study, impaired insulin secretion and insulin resistance in heterozygous $\mathrm{C} 3 \mathrm{H}-11^{\mathrm{NSY}}$ mice were similar to those in homozygous $\mathrm{C} 3 \mathrm{H}-11^{\mathrm{NSY}}$ mice, although not statistically significantly different from those in $\mathrm{C} 3 \mathrm{H}$ mice probably due to the small number of mice analyzed. In fact, when heterozygous $\mathrm{C} 3 \mathrm{H}-11^{\mathrm{NSY}}$ mice in the present study were compared with our previous data of $\mathrm{C} 3 \mathrm{H}$ mice [6], insulin secretion was significantly impaired and insulin resistance was marginally stronger in heterozygous $\mathrm{C} 3 \mathrm{H}-11^{\mathrm{NSY}}$ mice $(P<0.05$ and $P=0.07$, resp.; Mann-Whitney $U$ test). Further studies with a larger number of mice are necessary to clarify the underlying mechanisms of glucose intolerance in heterozygous $\mathrm{C} 3 \mathrm{H}-11^{\mathrm{NSY}}$ mice, in particular the contribution of impaired insulin secretion and insulin resistance to glucose intolerance. Such studies are now underway.

Genome-wide or large-scale association studies have revealed several candidate genes for type 2 diabetes [9-13], although the orthologues of these genes are not located on mouse Chr11. In mice, however, linkages with type 2 diabetes were reported on Chr11 in several different crosses [14-17]. This suggests the possibility that human orthologues of the diabetes-susceptibility gene(s) on mouse Chr11 are acting as rare variants in humans and therefore have not been detected by genome-wide association studies. Candidate genes on mouse Chr11 are hepatocyte nuclear factor-1 $\beta$, GLUT4, nucleoredoxin, and glucokinase [3, 5-7, 18, 19]. Human orthologues of these genes and other candidate genes on 


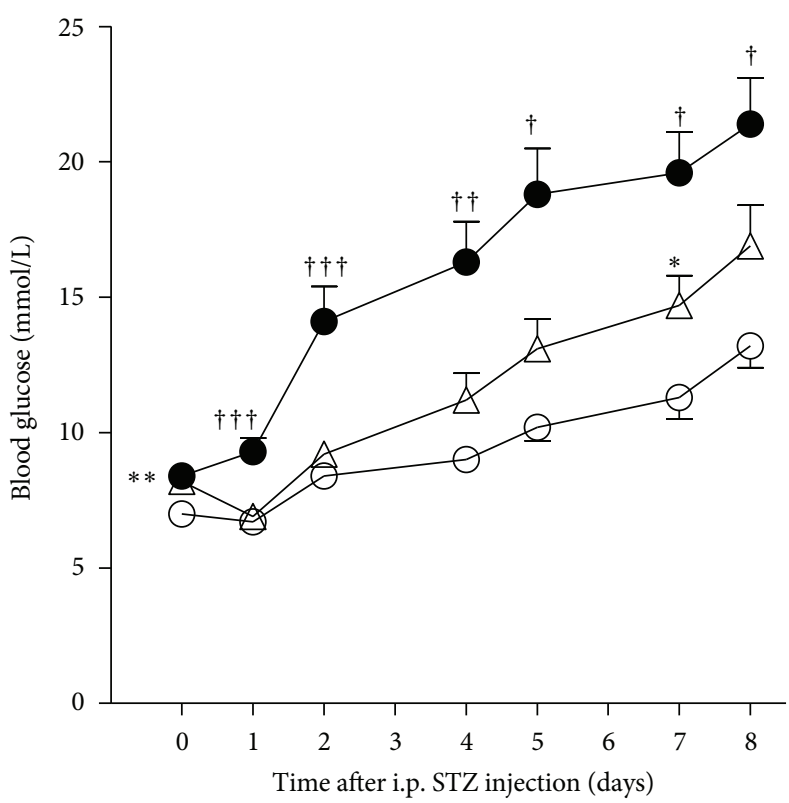

(a)

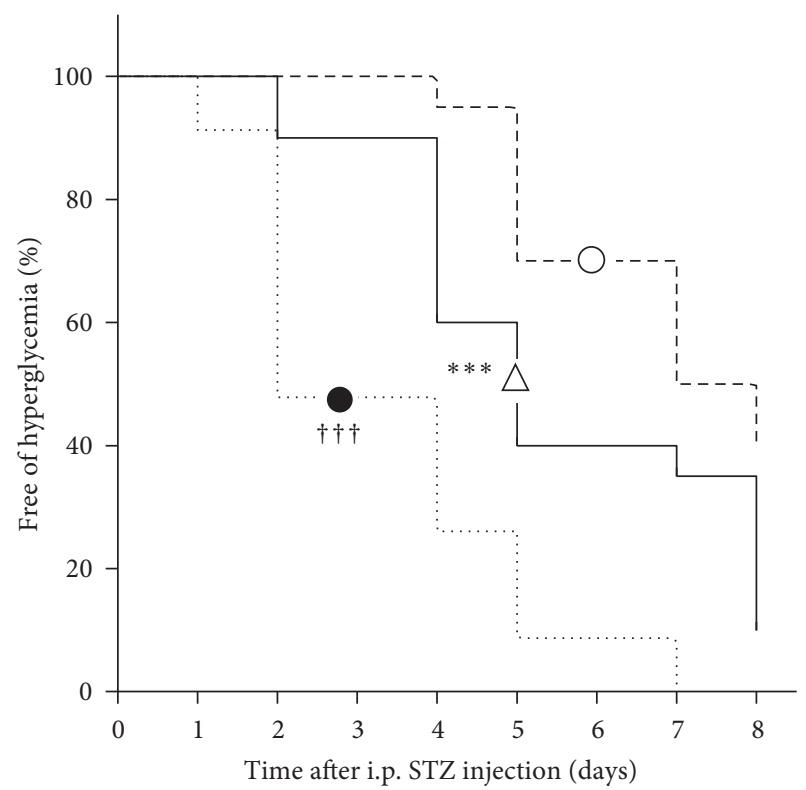

(b)

FIGURE 2: Streptozotocin sensitivity at 12 weeks of age in heterozygous C3H-11 ${ }^{\text {NSY }}$ ( $n=20$, white triangles), C3H mice ( $n=20$; white circles), and homozygous C3H-11 ${ }^{\mathrm{NSY}}(n=23$, black circles, [7]). The glucose concentration was determined $0,1,2,4,5,7$, and 8 days after a single intraperitoneal injection of streptozotocin at $175 \mathrm{mg} / \mathrm{kg}$ body weight. Blood glucose concentrations are presented as mean \pm SEM (a). The percentage of animals free of hyperglycemia (blood glucose level $>11.1 \mathrm{mmol} / \mathrm{L}$ ) is shown (b). ${ }^{*} P<0.05,{ }^{* *} P<0.01$, and ${ }^{* * *} P<0.001$ compared with $\mathrm{C} 3 \mathrm{H}$ and ${ }^{\dagger} P<0.05,{ }^{\dagger \dagger} P<0.01$, and ${ }^{\dagger \dagger} P<0.001$ compared with heterozygous C3H-1 ${ }^{\text {NSY }}$ (Mann-Whitney $U$ test for (a), log-rank test for (b)).

Chr11 are important candidates for genes explaining the socalled missing heritability in human type 2 diabetes.

\section{Conclusions}

These data indicated that the introgression of Chr11 of the diabetes-susceptible NSY strain onto diabetes-resistant $\mathrm{C} 3 \mathrm{H}$ caused marked changes in glucose tolerance and STZ susceptibility, even in heterozygous state, indicating that Chr11 harbors gene(s) responsible for hyperglycemia and STZ susceptibility, which is effective even in a single dose. Hyperglycemia and STZ sensitivity in heterozygous $\mathrm{C} 3 \mathrm{H}-11^{\mathrm{NSY}}$ mice, however, was not as severe as in homozygous $\mathrm{C} 3 \mathrm{H}-11^{\mathrm{NSY}}$ mice, suggesting that the mode of inheritance of a gene or genes on Chr11 for hyperglycemia and STZ sensitivity is additive. The difference in the dose effect and mode of inheritance for some phenotypes between the present study and our previous study with F1 mice suggests the genetic interaction between Chr11 and other chromosomes in determining the phenotypes. The consomic strains constructed in our studies will facilitate fine mapping and identification of responsible genes for diabetes-related phenotypes, as well as gene-gene and gene-environment interactions.

\section{Conflict of Interests}

The authors declare that they have no conflict of interests.

\section{Acknowledgments}

The authors thank Ms. M. Moritani for her skillful technical assistance and Dr. M. Shibata for his contribution to establishing the NSY colony and for the discussion. This study was supported by a Grant-in-Aid for Scientific Research from the Ministry of Education, Science, Sports and Culture, Japan. H. Ueda was supported through Special Coordination Funds for Promoting Science and Technology of the Ministry of Education, Culture, Sports, Science and Technology, the Japanese Government.

\section{References}

[1] M. K. Cavaghan, D. A. Ehrmann, and K. S. Polonsky, "Interactions between insulin resistance and insulin secretion in the development of glucose intolerance," The Journal of Clinical Investigation, vol. 106, no. 3, pp. 329-333, 2000.

[2] H. Ueda, H. Ikegami, E. Yamato et al., "The NSY mouse: a new animal model of spontaneous NIDDM with moderate obesity," Diabetologia, vol. 38, no. 5, pp. 503-508, 1995.

[3] H. Ueda, H. Ikegami, Y. Kawaguchi et al., "Age-dependent changes in phenotypes and candidate gene analysis in a polygenic animal model of Type II diabetes mellitus; NSY mouse," Diabetologia, vol. 43, no. 7, pp. 932-938, 2000.

[4] M. Itoi-Babaya, H. Ikegami, T. Fujisawa et al., "Fatty liver and obesity: phenotypically correlated but genetically distinct traits in a mouse model of type 2 diabetes," Diabetologia, vol. 50, no. 8, pp. 1641-1648, 2007. 
[5] H. Ueda, H. Ikegami, Y. Kawaguchi et al., "Genetic analysis of late-onset type 2 diabetes in a mouse model of human complex trait," Diabetes, vol. 48, no. 5, pp. 1168-1174, 1999.

[6] N. Babaya, T. Fujisawa, K. Nojima et al., "Direct evidence for susceptibility genes for type 2 diabetes on mouse chromosomes 11 and 14," Diabetologia, vol. 53, no. 7, pp. 1362-1371, 2010.

[7] N. Babaya, H. Ikegami, T. Fujisawa et al., "Susceptibility to streptozotocin-induced diabetes is mapped to mouse chromosome 11," Biochemical and Biophysical Research Communications, vol. 328, no. 1, pp. 158-164, 2005.

[8] H. Ueda, H. Ikegami, Y. Kawaguchi et al., "Paternal-maternal effects on phenotypic characteristics in spontaneously diabetic Nagoya-Shibata-Yasuda mice," Metabolism, vol. 49, no. 5, pp. 651-656, 2000.

[9] N. Bouatia-Naji, A. Bonnefond, C. Cavalcanti-Proença et al., "A variant near MTNR1B is associated with increased fasting plasma glucose levels and type 2 diabetes risk," Nature Genetics, vol. 41, no. 1, pp. 89-94, 2009.

[10] V. Lyssenko, C. L. F. Nagorny, M. R. Erdos et al., "Common variant in MTNR1B associated with increased risk of type 2 diabetes and impaired early insulin secretion," Nature Genetics, vol. 41, no. 1, pp. 82-88, 2009.

[11] I. Prokopenko, C. Langenberg, J. C. Florez et al., "Variants in MTNR1B influence fasting glucose levels," Nature Genetics, vol. 41, no. 1, pp. 77-81, 2009.

[12] I. Prokopenko, M. I. McCarthy, and C. M. Lindgren, “Type 2 diabetes: new genes, new understanding," Trends in Genetics, vol. 24, no. 12, pp. 613-621, 2008.

[13] E. Reiling, E. van 't Riet, M. J. Groenewoud et al., "Combined effects of single-nucleotide polymorphisms in GCK, GCKR, G6PC2 and MTNR1B on fasting plasma glucose and type 2 diabetes risk," Diabetologia, vol. 52, no. 9, pp. 1866-1870, 2009.

[14] I. Hirayama, Z. Yi, S. Izumi et al., "Genetic analysis of obese diabetes in the TSOD mouse," Diabetes, vol. 48, no. 5, pp. 1183-1191, 1999.

[15] E. H. Leiter, P. C. Reifsnyder, K. Flurkey, H. J. Partke, E. Junger, and L. Herberg, "Niddm genes in mice: deleterious synergism by both parental genomes contributes to diabetogenic thresholds," Diabetes, vol. 47, no. 8, pp. 1287-1295, 1998.

[16] S. Takeshita, M. Moritani, K. Kunika, H. Inoue, and M. Itakura, "Diabetic modifier QTLs identified in F2 intercrosses between Akita and A/J mice," Mammalian Genome, vol. 17, no. 9, pp. 927-940, 2006.

[17] A. A. Toye, J. D. Lippiat, P. Proks et al., "A genetic and physiological study of impaired glucose homeostasis control in C57BL/6J mice," Diabetologia, vol. 48, no. 4, pp. 675-686, 2005.

[18] H. Ueda, H. Ikegami, Y. Kawaguchi et al., "Mapping and promoter sequencing of HNF- $1 \beta$ gene in diabetes-prone and -resistant mice," Diabetes Research and Clinical Practice, vol. 53, no. 2, pp. 67-71, 2001.

[19] K. Yamada, H. Ikegami, Y. Kawaguchi et al., "Sequence analysis of candidate genes for common susceptibility to type 1 and type 2 diabetes in mice," Endocrine Journal, vol. 48, no. 2, pp. 241-247, 2001. 


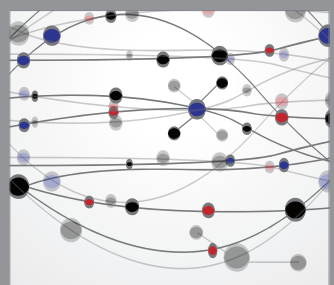

The Scientific World Journal
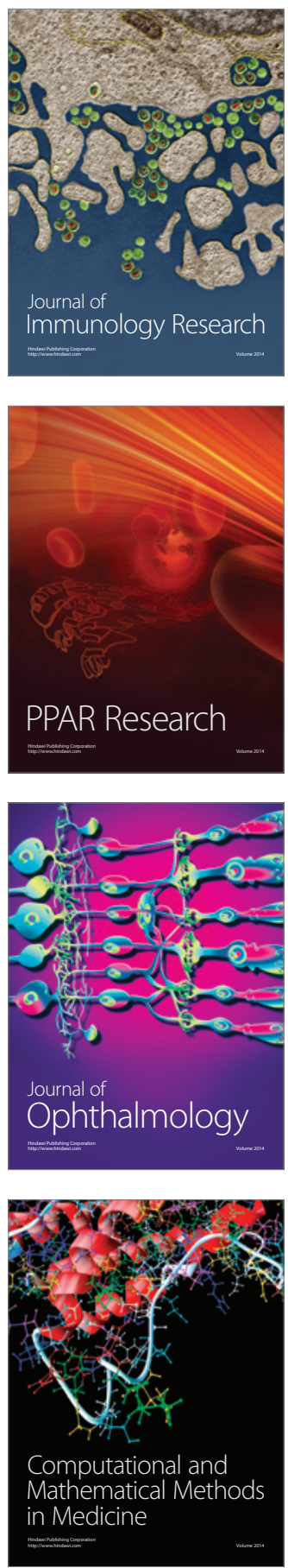

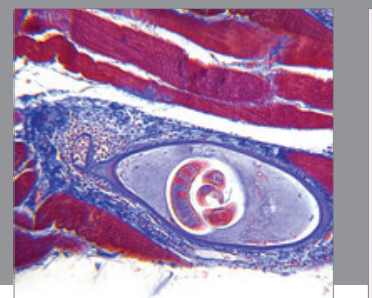

Gastroenterology

Research and Practice
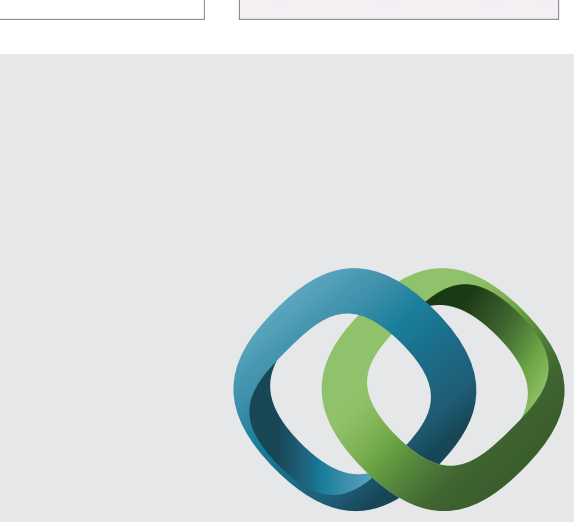

\section{Hindawi}

Submit your manuscripts at

http://www.hindawi.com
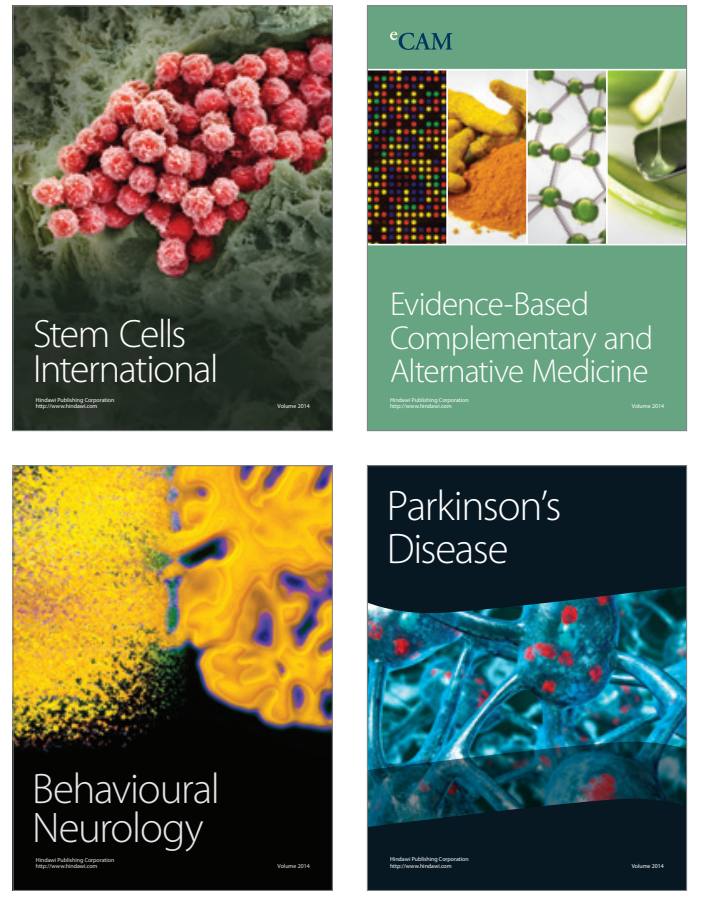
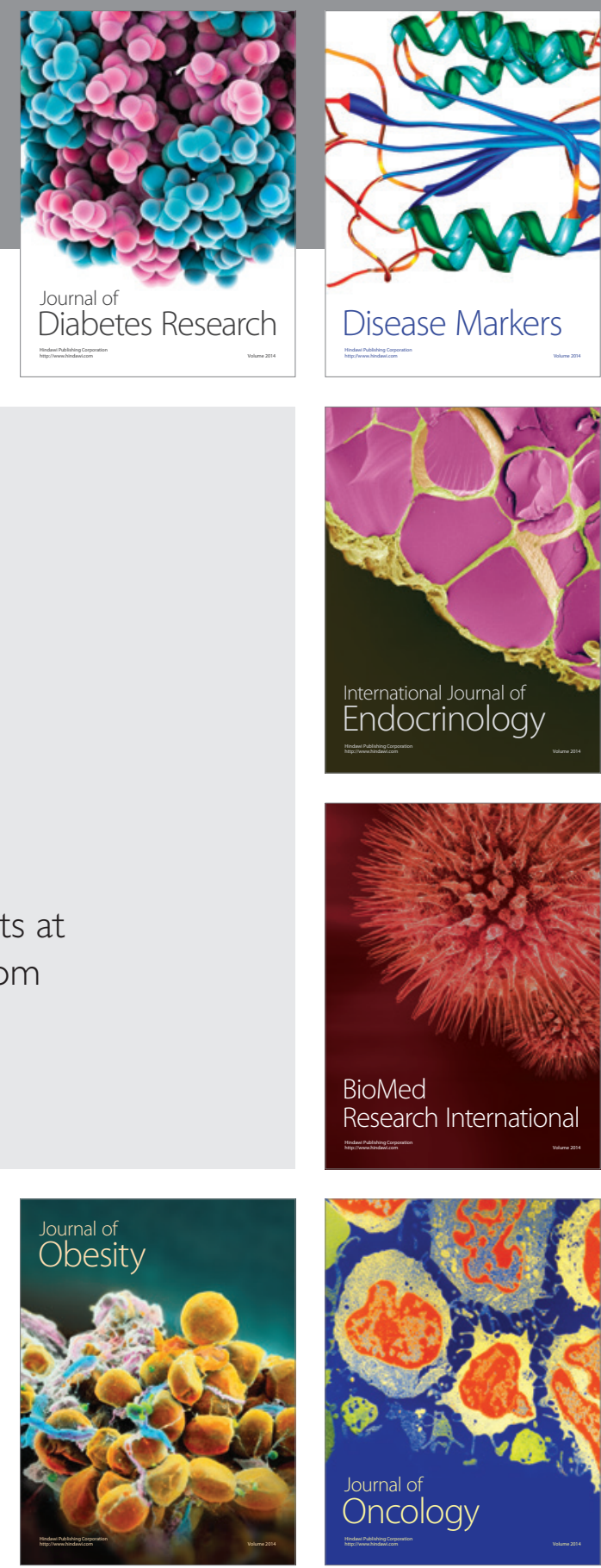

Disease Markers
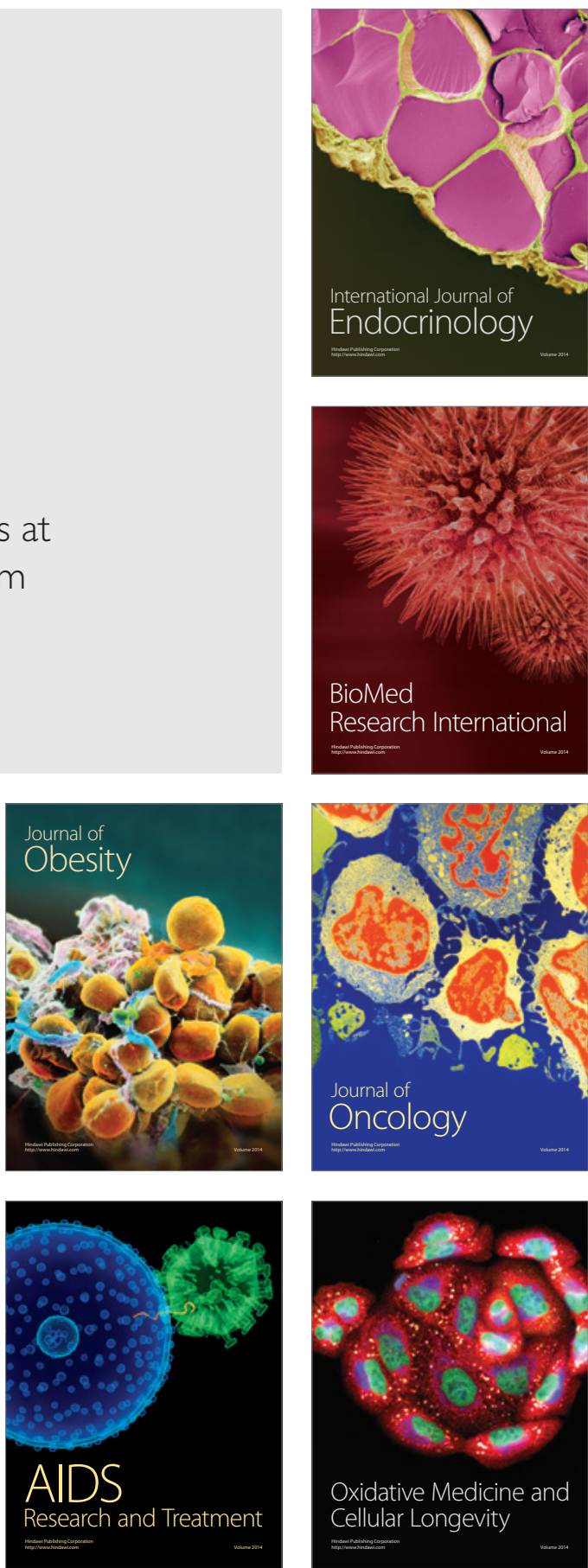